\title{
Isolasi dan Karakterisasi Selulase dari Trichoderma Viride dan Rhizopus Spp dengan Substrat Jerami Padi
}

\author{
Montesyrit \\ Jurusan Nutrisi Makanan Ternak Fakuhas Peternakan Universitas Andaias, Padang
}

\begin{abstract}
The objectives of this study were to isolated and produce cyllulase from soil molds and to characterize the enzyme. The strains of mold isolated from soil, namely Rhizopus spp and one cultured mold, Trichoderma viride, was used to produce the enzymes. Mediam for enzyme production consisted of $\mathrm{NH}_{4} \mathrm{NO}_{3}, \mathrm{KCl}, \mathrm{FeSO}_{5} 7 \mathrm{H}_{2} \mathrm{O}, \mathrm{MgSO}_{4} 7 \mathrm{H}_{2} \mathrm{O}, \mathrm{CuSO}$, $2 \mathrm{H}_{2} \mathrm{O}$ and rice straw as a sole source of carbon $(\mathrm{pH}=5,45)$. ('ulture was done at $28^{\circ} \mathrm{C}$ for $5,8,11$ and 14 days with shaking at $150 \mathrm{rpm}$. Using this method cellulase production was optimum at 14 days with substrat concentration of $1.5 \%$ for 7 . viride culture. However the optimum production of cellulase for Rhizopus spp culhure were three days shorter than culture of $T$ viride with substrat cancentration of 1.5 and $1 \%$ respectively. Temperature and $\mathrm{pH}$ optimal acrivity of cellulases were as follow : cellulase from $T$. viride at temperature $60^{\circ} \mathrm{C}$ and $\mathrm{pH} 5$ and cellulase from Rhizopus spp at temperature $50^{\circ} \mathrm{C}$ and $\mathrm{pH}$ 5. While temperature and $\mathrm{pH}$ stability of cellulases were as follow : cellulase from $T$. viride at temperature $30-80^{\prime} \mathrm{C}$ and $\mathrm{pH} 3-7$ and cellulase from Rhizopus spp at temperature $30-80^{\circ} \mathrm{C}$ and $\mathrm{pH} 3-6$. It was conchided that molds can grow on rice straw as a sole source of carbon produce cellulases.
\end{abstract}

Key words : cellulases, mold, rice straw

\section{Pendahuluan}

Kemungkinan untuk mengekstraksi enzim dari mikroorganisme tanah di Indonesia cukup terbuka, hal ini disebabkan karena jenis tanah yang ada berbeda-beda dan juga karena banyaknya tersedia limbah hasil pertanian untuk media tumbuh dan substrat fermentasi. Hasil penelitian sebelumnya telah diisolasi kapang dari tanah dengan menggunakan jerami padi sebagai sumber karbon (Soetjiharto, 1997). Kapang tersebut dapat ditumbuhkan pada media yang mengandung limbah berserat hasil pertanian dan diduga dapat menghasilkan enzim selulase. Enzim selulase dapat dipakai untuk memecah ikatan lignoselulosa dari limbah berserat hasil pertanian sehingga dapat dimanfaatkan oleh ternak dengan baik. Selama ini belum banyak penelitian yang memanfaatkan enzim selulase yang berasal dari kapang yang dísolasi dari tanah dengan menggunakan bahan limbah berserat sebagai satusatunya sumber karbon dalam media tumbuh.

Enzim dapat diproduksi dengan cara mengekstraksi dari tanaman, hewan dan mikroorganisme. Memproduksi enzim dari mikroba lebilh menguntungkan karena mudah dibiakkan, mempunyai kecepatan tumbuh yang tinggi dan mudah dikontrol pertumbuhannya (Darwis dan Sukara, 1990). Menurut Landecker (1972) diantara mikroorganisme tanah yang ada ternyata kapang merupakan spesies yang paling tinggi kemampuan hidupnya dan juga daya bersaing tinggi dibandingkan lainnya. Hal ini disebabkan oleh laju pertumbuhan dan germinasi yang tinggi, efisiensi tingkat metabolik yang tinggi dalam menghasilkan enzim serta mempunyai kemampuan memproduksi 
senyawa tertentu seperti antibiotik yang bersifat toksik bagi mikroorganisme lainnya.

Mikroorganisme penghasil enzim selulase adalah kapang dan bakteri. Kapang merupakan penghasil enzim selulase dan ligninase yang paling sering diteliti. Kapang yang baik untuk memproduksi enzim selulase adalah Trichoderma reesei, $T$. viride, $T$. koninggit, Aspergillus terreus, A niger, Penicillium verruculosum, $P$ fumiculosum, Fusarium sola dan Phanerochaeta chrysosporium (Enari, 1983). Dibandingkan dengan kapang, spesies bakteri dianggap kurang efisien digunakan sebagai penghasil enzim selulase, selain itu sedikit sekali data tentang bakteri penghasil enzim ini. (Aunstrup, 1979).

Kondisi yang berpengaruh dalam produksi enzim dari mikroorganisme adalah $\mathrm{pH}$ dan suhu fermentasi. Nilai $\mathrm{pH}$ optimum untuk memproduksi enzim bervariasi, tergantung pada jenis kapang, macam fermentasi dan substrat yang digunakan. Bagi fermentasi cair selain macam substrat, jumlah selulosa yang digunakan perlu diperhatikan. Apabila digunakan terlalu banyak maka pengadukan media selama fermentasi kurang sempurna, sebaiknya digunakan selulosa maksimum sebanyak $10 \%$ (Tangiu et al., 1981).

Sebagai sumber karbon di dalam media tumbuh mikroorganisme penghasil selulase digunakan selulosa murni dan alami. Selulosa alami yang biasa digunakan merupakan limbah hasil pertanian, seperti serbuk gergaji, jerami padi, bagas tebu dan sebagainya (Chahal, 1985). Menurut Considine dan Coughlan (1989) hasil dan komposisi enzim yang diproduksi dari limbah pertanian dipengaruhi oleh pemilihan mikroorganisme, jenis substrat dan sistem kultivasi. Selanjutnya Jorgensen dan Cowan (1989) menyatakan dalam ekplorasi enzim dipengaruhi oleh faktor-faktor seperti komposisi substrat, kosentrasi substrat, ketersediaan substrat, dosis enzim, waktu, $\mathrm{pH}$ dan temperatur.

Teknologi pemanfaatan enzim mendapat prioritas untuk dikembangkan di Indonesia karena banyaknya limbah berserat hasil pertanian yang dapat digunakan sebagai media tumbuh mikroba. Hambatan utama pengembangan teknologi enzim terletak pada tingginya biaya produksi enzim, sehingga nilai ekonomi enzim yang dihasilkan menjadi sangat mahal. Pemanfaatan limbah industri hasil pertanian seperti jerami padi sebagai media tumbuh mikroorganisme pengganti bahan-bahan kimia sintetik yang mahal, merupakan salah satu cara untuk mengurangi biaya produksi. Tujuan dari penelitian ini adalah untuk mengekstraksi selulase dari kapang tanah dengan jerami padi sebagai media tumbuh serta untuk mempelajari sifat - sifat enzim tersebut.

\section{Materi Dan Metode}

Penelitian ini dilaksanakan dengan menggunakan bahan-bahan kimia yang tersedia secara komersil meliputi: larutan mineral untuk medium fermentasi yang terdiri dari: $\mathrm{NH}_{4} \mathrm{NO}_{3}, \mathrm{KCl}, \mathrm{FeSO}_{4} 7 \mathrm{H}_{2} \mathrm{O}, \mathrm{MgSO}_{4}$ $7 \mathrm{H}_{2} \mathrm{O}, \mathrm{CuSO}_{4}$, ekstrak ragi dan pepton. Mikroorganisme yang digunakan dalam penelitian ini adalah 2 jenis kapang yakni kapang yang di isolasi dari tanah (kapang Rhizopus spp) dengan menggunakan jerami padi sebagai satu - satunya 
sumber karbon dalam media tumbuhnya (Soetjiharto, 1997) dan kapang komersial Trichoderma viride yang diperoleh dari Laboratorium Biotekhnologi LIPI Bogor.

\section{Isolasi Enzim}

Untuk isolasi enzim digunakan media yang terdiri dari $0,5 \%$ $\mathrm{NH}_{4} \mathrm{NO}_{3}, 0,05 \% \mathrm{KCl}, 0,001 \%$ $\mathrm{FeSO}_{4} 7 \mathrm{H}_{2} \mathrm{O}, 0,05 \% \quad \mathrm{MgSO}_{4} 7 \mathrm{H}_{2} \mathrm{O}$ dan $0,0001 \% \mathrm{CuSO}_{4} 2 \mathrm{H}_{2} \mathrm{O}$ (Ramli, 1995) dan sebagai satu-satunya sumber karbon digunakan jerami padi dengan konsentrasi $0,5,1,1,5$ dan $2 \%$. Satu lup bahan kapang ditumbuhkan ke dalam tabung yang telah berisi media, di inkubasi selama 4 hari dengan goyangan pada suhu kamar, kemudian di transfer ke erlenmeyer $250 \mathrm{ml}$ yang berisi media dan substrat jerami padi dan di inkubasi dengan goyangan selama 5 , 8,11 dan 14 hari pada suhu kamar. Supernatan sebagai enzim kasar diperoleh dengan cara sentrifugasi pada kecepatan $3000 \mathrm{rpm}$ selama 20 menit dan kemudian di ukur aktivitas carboxy methyl celulase (CMC-ase), $\beta$ glukosidase dan fitter paperase (FP-ase) menurut metode Mandels et al (1976a). Konsentrasi substrat dan waktu fermentasi yang dapat menghasilkan aktivitas optimum dipakai untuk metoda penelitian enzim selanjutnya.

\section{Ekstraksi Enzim}

Supernatan dari masing-masing enzim direaksikan dengan amonium sulfat dengan kejenuhan $50-60 \%$ dan kemudian di sentrifugasi pada kecepatan $10.000 \mathrm{rpm}$ selama 15 menit pada suhu $4^{\circ} \mathrm{C}$. Endapan sebagai enzim kasar yang diperoleh dilarutkan dalam buffer phosfat 0,01
$\mathrm{M}(\mathrm{pH} 7)$ dan siap digunakan untuk penelitian selanjutnya.

\section{Pengaruh pH dan Suhu terhadap} Aktivitas dan Stabilitas Enzim

Penentuan pengaruh $\mathrm{pH}$ terhadap aktivitas enzim optimum ditentukan dengan cara menempatkan enzim dalam berbagaj $\mathrm{pH}$ antara $\mathrm{pH} 3$ sampai 9 dan di ukur aktivitas enzimnya, sedangkan untuk mengetahui pengaruh suhu terhadap aktivitas enzim optimum dilakukan dengan cara mengukur aktivitas enzim dalam berbagai suhu yaitu suhu $30,40,50,60,70$ dan $80^{\circ} \mathrm{C}$,

Pengamatan pengaruh $\mathrm{pH}$ tehadap stabilitas enzim dilakukan dengan cara menempatkan filtrat enzim dalam $0,05 \mathrm{M}$ buffer-buffer pada berbagai $\mathrm{pH}$ selama 24 jam pada suhu $5^{0} \mathrm{C}$ kemudian di ukur aktivitasnya. Untuk melihat pengaruh suhu terhadap stabilitas enzim dengan cara menempatkan enzim pada suhu $30,40,50,60,70$ dan $80^{\circ} \mathrm{C}$ selama beberapa menit dan kemudian di ukur aktivitasnya (Ramli, 1995). Pengukuran aktivitas enzim dilakukan sama seperti prosedur sebelumnya.

Dalam pengujian aktivitas enzim digunakan $\mathrm{CMC}$, salisin. kertas whatman no.1, buffer sitrat, DNS $(3,5$, Dinitro salicylic acid). Penentuan pengaruh suhu terhadap aktivitas enzim digunakan berbagai buffer seperti buffer sitrat $0,05 \mathrm{M}$, buffer posfat $0,05 \mathrm{M}$ dan buffer borat $0.05 \mathrm{M}$.

\section{Hasil Dan Pembahasan}

\section{Penentuan Konsentrasi Substrat dan Lama Fermentasi}

Pengaruh konsentrasi substrat jerami padi $(0,0,5,1,0,1,5$ dan $2 \%)$ dalam medium fermentasi terhadap 
aktivitas carboxy metyl celulase (CMC-ase), $\beta$-glukosidase dan filter paperase (FP-ase) yang dihasilkan dari kapang $T$. Viride, dan Rhizopus spp dapat dilibat pada Gambar 1. Aktivitas selulase (CMCase, $\beta$ glukosidase dan $\mathrm{FP}$-ase) optimum dari kapang $T$. viride terjadi pada pemberian konsentrasi substrat $1,5 \%$ (Gambar 1A) sedangkan pada kapang Rhizopus spp aktivitas selulase optimum terjadi pada pemberian konsentrasi substrat 1,0\% (Gambar 1B).

Pemberian konsentrasi substrat di atas 1,5\% untuk kapang $T$, viride dan $1,0 \%$ untuk kapang Rhizopus spp pada medium fermentasi menyebabkan terjadinya penurunan aktivitas selulase dari semua kultur yang digunakan. Hal ini kemungkinan disebabkan dengan meningkatnya konsentrasi jerami padi yang ditambahkan menyebabkan medium fermentasi menjadi agak kental serta pengadukan media selama fermentasi kurang sempurna sehingga menimbulkan masalah dalam sirkulasi oksigen, selanjutnya mengakibatkan pertumbuhan kapang terganggu dan produksi enzim per$\mathrm{ml}$ supernatan rendah. Pemberian konsentrasi substrat dibawah optimum menyebabkan terbatasnya sumber karbon sehingga pertumbuhan kapang terganggu dan aktivitas enzim menurun. Mandels et al. (1976b) menyatakan produksi enzim selulase dari $T$, reesei dalam kultur batch akan mencapai hasil yang baik dengan menggunakan konsentrasi selulosa 1,5\% tanpa pengontrolan $\mathrm{pH}$, dan penurunan $\mathrm{pH}$ akan diikuti dengan penurunan aktivitas enzim.

Pemakaian konsentrasi substrat $0 \%$ ternyata tidak dapat menghasilkan enzim selulase (aktivitas CMC-ase, $\beta$-glukosidase dan FP-ase tidak dapat dideteksi). Hal ini menunjukkan bahwa kedua kapang tersebut dalam menghasilkan selulase perlu adanya induser untuk merangsang terbentuknya enzim. Menurut Gong dan Tsao (1979) induser terhadap sintesis enzim selulase pada mikroba yaitu selobiosa, selulosa, sophorosa dan laktosa, kesemuanya dapat digunakan sebagai sumber karbon oleh mikroba tersebut. Selanjutnya ditambahkan oleh Chalhal (1985) selulosa alami yang merupakan limbah hasil pertanian seperti: jerami padi, serbuk gergaji, ampas tebu dan sebagainya dapat digunakan sebagai sumber karbon oleh mikroba penghasil selulase.

Dari hasil pengukuran aktivitas selulase selama fermentasi terlihat bahwa fermentasi hari ke-14 pada kapang $T$. viride diperoleh aktivitas selulase maksimum (Gambar 2A), hal ini didukung oleh hasil penelitian Ekawati (1993) yang menyatakan bahwa aktivitas CMCase dan $\beta$ glukosidase dari $T$ reesei sampai hari ke 11 masih mengalami peningkatan, sedangkan pada kapang Rhizopus spp aktivitas selulase maksimum diperoleh pada lama fermentasi 11 hari (Gambar 2B). 

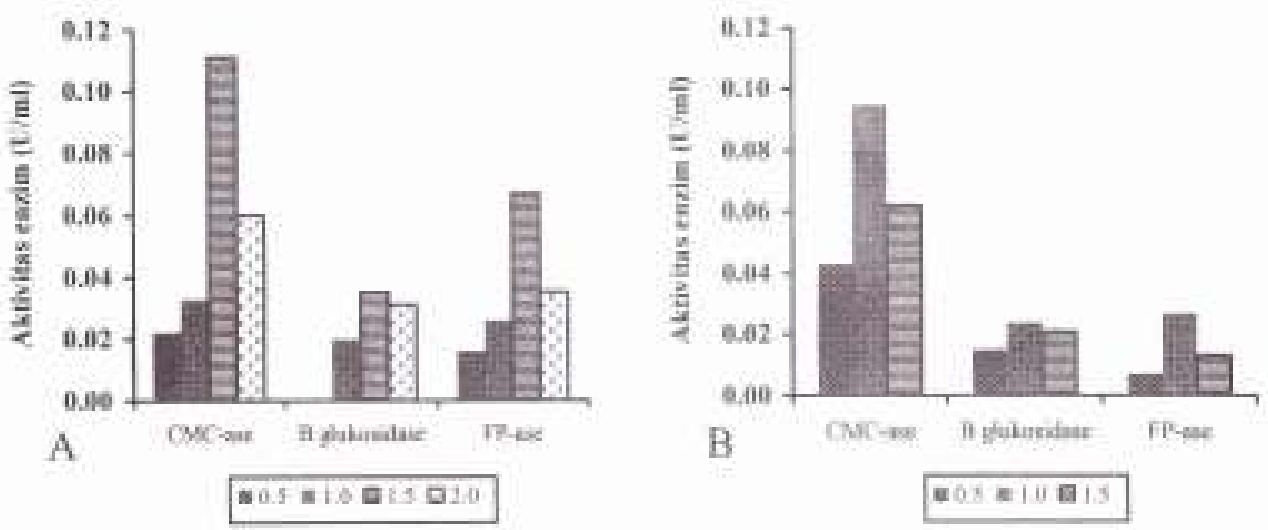

Gambar 1. Aktivitas CMC-ase, $\beta$ Glukosidase dan FP-ase pada berbagai konsentrasi substrat dari kapang T. viride (A) dan kapang Rhizopus $\operatorname{spp}(\mathrm{B})$.
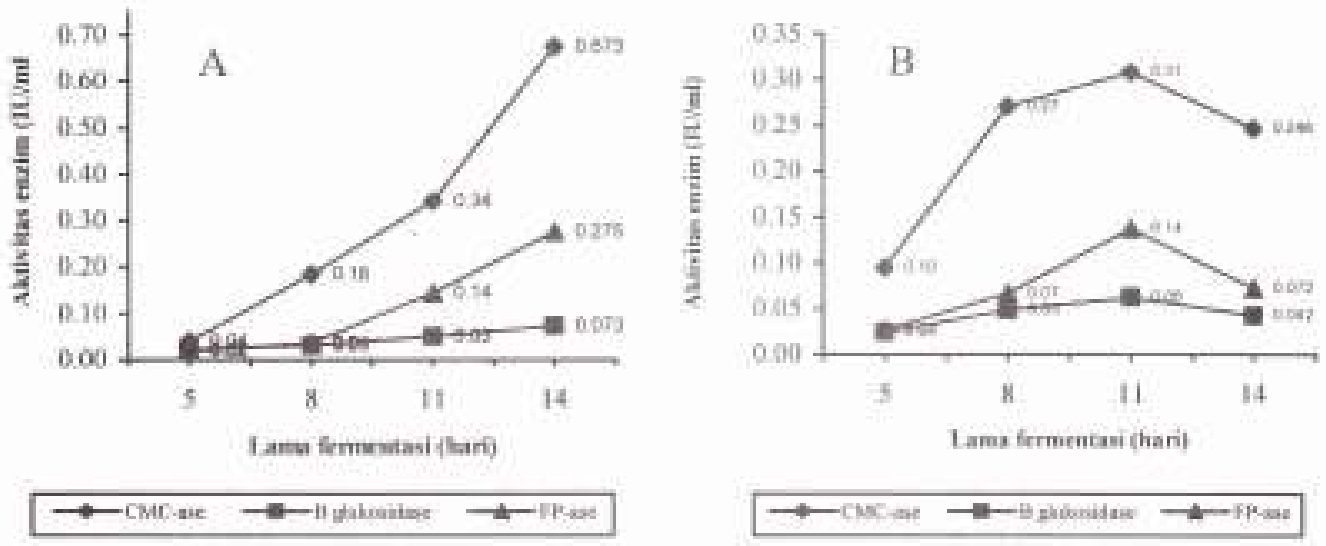

Gambar 2. Pengaruh lama fermentasi terhadap produksi enzim oleh kapang $T$. viride (A) dan kapang Rhizopus spp (B).

Dari kedua isolat kapang terlihat bahwa hasil pengukuran aktivitas $\mathrm{CMC}$ - ase lebih tinggi dibandingkan dengan aktivitas $\beta$ glukosidase dan FP-ase, Aktivitas CMC-ase terutama menunjukkan aktivitas endoselulase yang secara acak memutus ikatan pada bagian amorf selulosa yang sangat mudah mengalami hidrolisis (Irawadi, 1991). Selanjutnya Mandels et al (1976a) menyatakan bahwa bagian amorf selulosa dapat dihidrolisis dengan cepat dan kecepatan hidrolisis ini akan menurun dengan semakin banyaknya daerah kristal selulosa yang diserang enzim sclulase tersebut, Aktivitas FP-ase yang diperoleh juga lebih tinggi dibanding aktivitas $\beta$-glukosidase. Rendahnya aktivitas $\beta$-glukosidase yang diperoleh dari kapang Trichoderma didukung oleh pernyataan Stenberg (1976) yang melaporkan bahwa Trichoderma menghasilkan $\beta$-glukosidase dalam jumlah yang relatif rendah. Aktivitas $\beta$-glukosidase maksimum dari kapang $T$ viride diperoleh pada lama fermentasi 14 hari yaitu sebesar $0,073 \mathrm{IU} / \mathrm{ml}$. Hasil ini mendekati hasil penelitian Peiji (1987) yang 
mendapatkan aktivitas $\beta$ glukosidase dengan penggunaan substrat salisin pada enzim $T$, reesei mutan R-10 sebesar $0.092 \mathrm{IU} / \mathrm{ml}$. Breuil et al. (1986) menyatakan salisin atau saligenin $\beta$-D-glukopiranoside sering dipakai sebagai substrat standar penentuan aktivitas $\beta$ glukosidase. Aktivitas CMC- ase dari $T$ viride dengan lama fermentasi 14 hari didapatkan sebesar $0,673 \mathrm{IU} / \mathrm{ml}$. Hasil ini lebih tinggi jika dibandingkan dengan penelitian Sutopo (1987) yang mendapatkan aktivitas $\mathrm{CMC}$-ase dari $T$ viride dengan substrat fermentasi jerami padi sebesar 0,5411 $\mathrm{IU} / \mathrm{ml}$. Dari kedua enzim tersebut terlihat aktivitas selulase dari kapang Trichoderma viride lebih tinggi dari aktivitas kapang Rhizopus spp.

\section{Pengaruh pH terhadap Aktivitas dan Stabilitas Enzim}

Dua macam enzim kasar (enzim dari kapang $T$ viride dan Rhizopus spp) yang telah diperoleh setelah diendapkan dengan amonium sulfat pada tingkat kejenuhan optimum, diuji aktivitas dan stabilitasnya terhadap pengaruh suhu dan $\mathrm{pH}$. Pengaruh perubahan $\mathrm{pH}$ terhadap aktivitas CMC-ase dan FP.

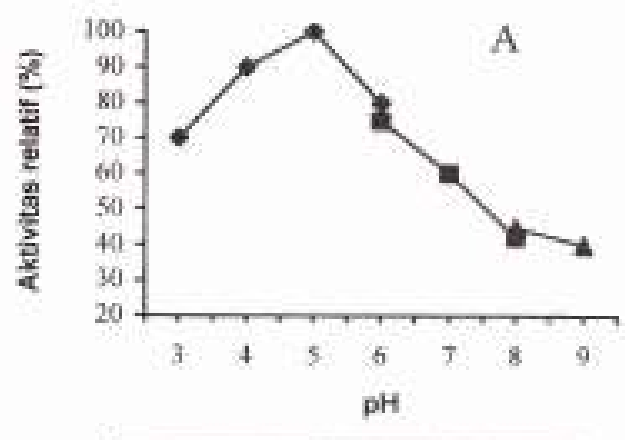

- silrat $-\mathbf{E}-$ posfat - -borat ase yang dihasilkan enzim dari $T$. viride dan Rhizopus spp menunjukkan bahwa nilai $\mathrm{pH}$ yang menghasilkan aktivitas $\mathrm{CMC}$-ase dan FP-ase optimum terjadi pada $\mathrm{pH} 5$ untuk kedua enzim dari $T$. viride dan Rhizopus spp (Gambar 3 dan Gambar 4). Aktivitas selulase optimum yang diperoleh dari ke 2 macam enzim tersebut termasuk dalam kisaran yang dinyatakan Kulp (1975) bahwa $\mathrm{pH}$ optimum untuk aktivitas selulase adalah sekitar $\mathrm{pH} 4,5-6,5$. Pada penelitian ini nilai $\mathrm{pH}$ yang menghasilkan aktivitas selulase optimum dari kapang $T$. viride adalah pada $\mathrm{pH} 5$, hasil ini mendekati hasil penelitian Martin et al (1987) yang mendapatkan aktivitas enzim optimum dari kapang $T$ reesei yaitu pada kisaran $\mathrm{pH} 4,3-$ 4,8 .

Pada umumnya enzim hanya aktif pada kisaran $\mathrm{pH}$ yang terbatas. Adanya $\mathrm{pH}$ optimum yang dimiliki enzim atau menurunnya aktivitas pada kedua sisi lainnya disebabkan oleh turunnya afinitas atau stabilitas enzim. Pengaruh $\mathrm{pH}$ pada aktivitas enzim disebabkan oleh terjadinya perubahan tingkat ionisasi pada enzim atau substrat (Irawadi, 1991).

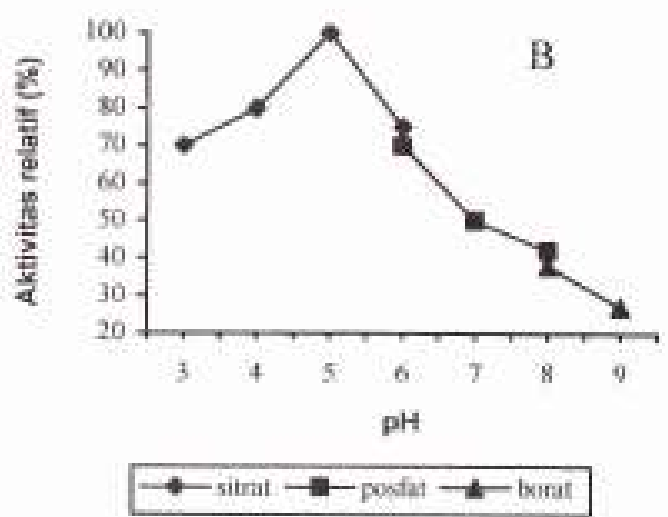

Gambar 3. Pengaruh $\mathrm{pH}$ terhadap aktivitas $\mathrm{CMC}$-ase (A) dan FP-ase (B) pada kapang $T$, viride 

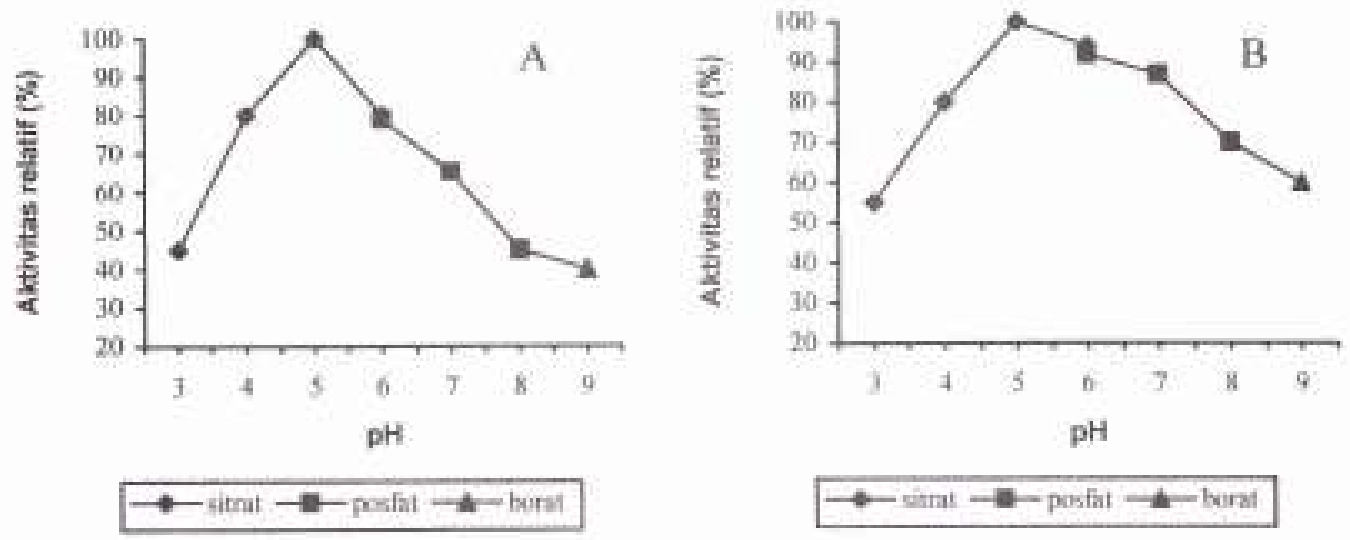

Gambar 4. Pengaruh pH terhadap aktivitas CMC-ase (A) dan FP-ase (B) pada kapang Rhizopus spp
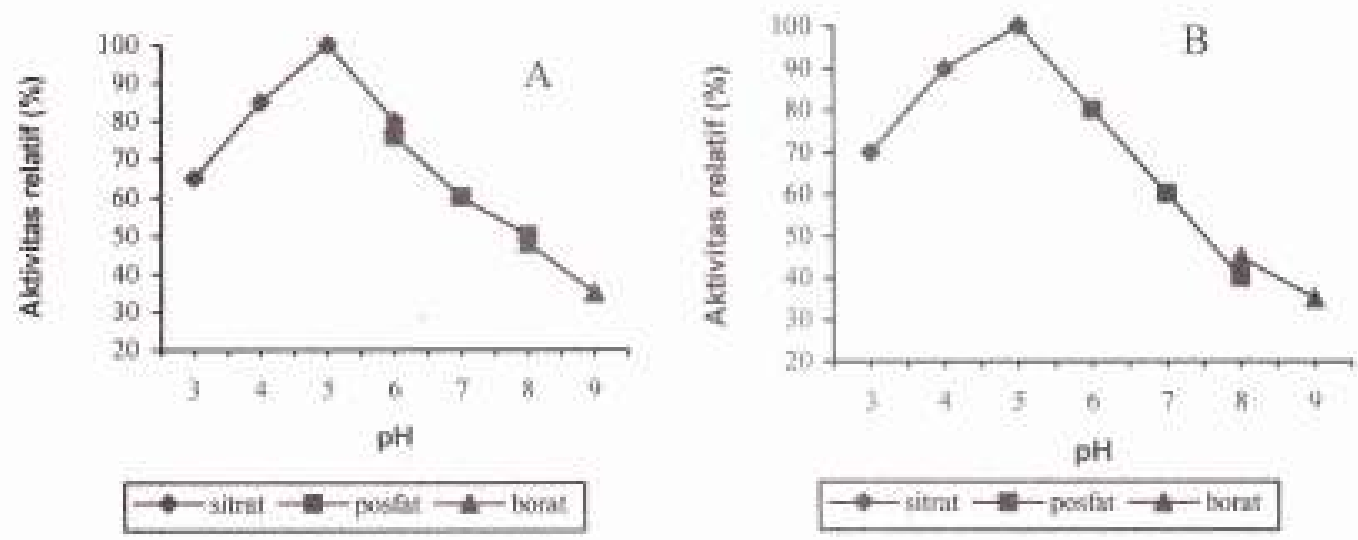

Gambar 5. Stabilitas enzim CMC-ase (A) dan FP-ase (B) pada berbagai pH dari kapang $T$. viride
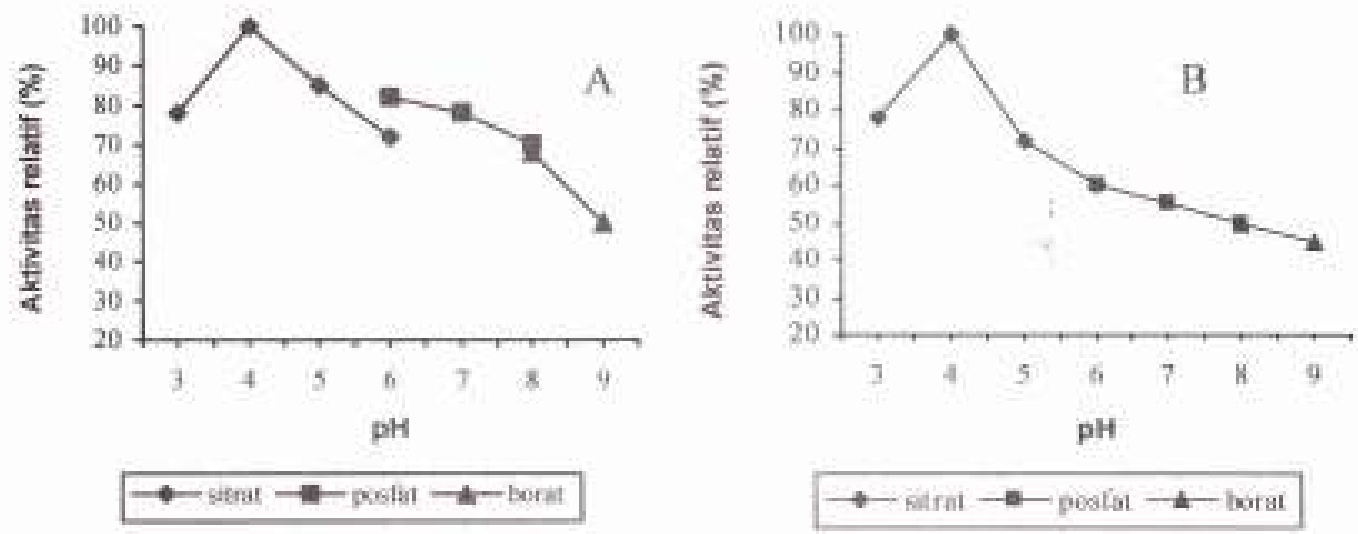

Gambar 6. Stabilitas enzim CMC-ase (A) dan FP-ase (B) pada berbagai pH dari kapang Rhizopus spp 
Pengaruh perubahan $\mathrm{pH}$ pada stabilitas enzim pada suhu $4^{\circ} \mathrm{C}$ selama 24 jam menunjukkan bahwa enzim dari kapang Rhizopus spp lebih stabil pada kisaran $\mathrm{pH} \mathrm{3-6}$ (Gambar 6) dan enzim dari kapang $T$ viride akan stabil pada kisaran $\mathrm{pH} 3$ - 7 (Gambar 5) dimana dapat menghasilkan aktivitas CMC -ase dan FP-ase optimum. Hasil ini mendekati dengan hasil penelitian Okada (1985) yang mendapatkan aktivitas $\mathrm{CMC}$-ase yang dihasilkan oleh $A$. niger dapat stabil selama 24 jam pada suhu $4^{\circ} \mathrm{C}$ pada kisaran $\mathrm{pH} 5$ sampai 8.

\section{Pengaruh Suhu terhadap Aktivitas dan Stabilitas Enzim}

Untuk mengetahui pengaruh suhu terhadap aktivitas enzim, maka enzim ditempatkan pada $\mathrm{pH}$ dan bufer yang menghasilkan aktivitas optimum, kemudian enzim tersebut diinkubasikan pada suhu 30 sampai suhu $80^{\circ} \mathrm{C}$ dan diukur aktivitas enzimnya pada kondisi standar. Aktivitas $\mathrm{CMC}$-ase dan FP-ase dari enzim $T$, viride akan mencapai optimum pada suhu $60^{\circ} \mathrm{C}$ (Gambar 7) sedangkan enzim dari Rhizopus spp aktivitasnya akan mencapai optimum pada suhu $50^{\circ} \mathrm{C}$ (Gambar 8). Mandels et al (1976a) menyatakan

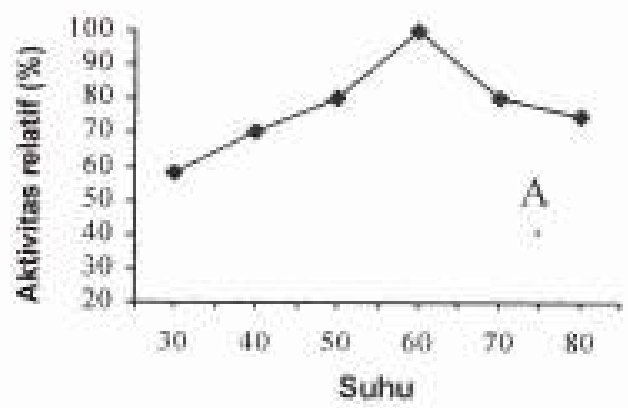

bahwa suhu optimum untuk kerja enzim selulase bervariasi tergantung pada jenis mikroba penghasil enzim tersebut, tetapi pada umumnya selulase menunjukan suhu optimum antara $50-60^{\circ} \mathrm{C}$. Aktivitas enzim selulase optimum dari kapang $T$ reesei adalah antara 50 dan $55^{\circ} \mathrm{C}$ (Martin et al, 1987). Selanjutnya Mandels et al. (1976a) mendapatkan bahwa aktivitas selulase dari $T$. viride pada suhu $60^{\circ} \mathrm{C}$ lebih tinggi bila dibandingkan dengan pada suhu $50^{\circ} \mathrm{C}$ dan $40^{\circ} \mathrm{C}$.

Turunnya aktivitas pada suhu dibawah suhu optimum diduga disebabkan rendahnya afinitas antara enzim dengan substrat atau rendahnya kecepatan awal pemutusan kompleks enzim substrat. Sedangkan turunnya aktivitas pada suhu diatas suhu optimum terutama disebabkan menurunnya stabilitas enzim akibat panas. Pemberian panas dapat menyebabkan putusnya sebagian besar ikatan-ikatan yang kurang kuat pada struktur protein enzim. misalnya ikatan hidrogen yang membentuk tersier protein, yang akhimya dapat menyebabkan denaturasi pada enzim (Irawadi, 1991).

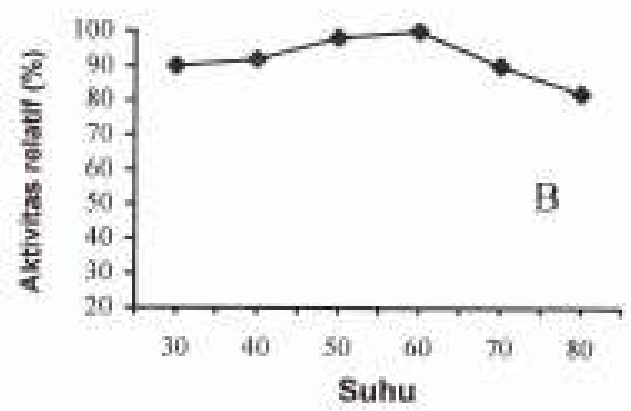

Gambar 7. Pengaruh suhu terhadap aktivitas CMC-ase (A) dan FP-ase (B) pada kapang $T$, viride 

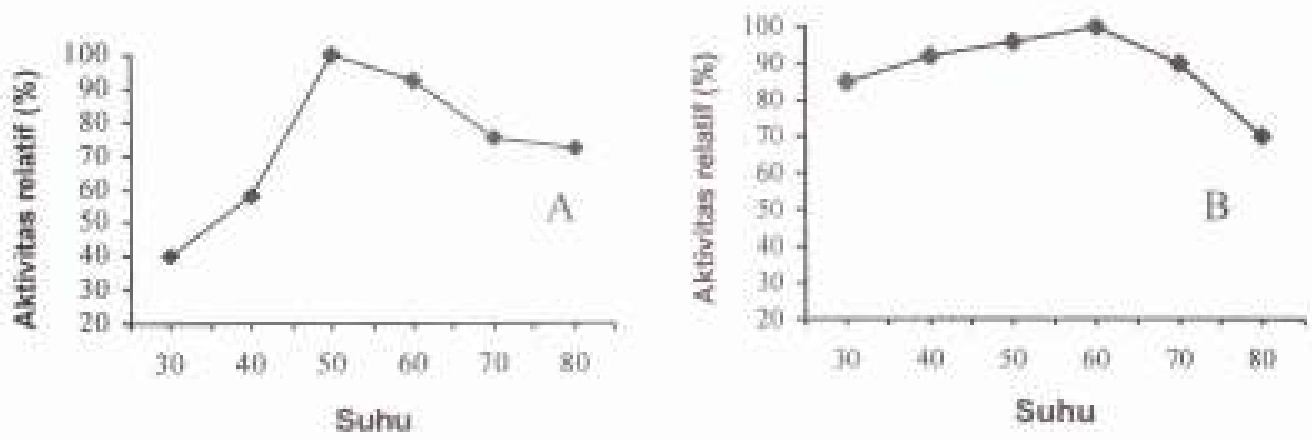

Gambar 8. Pengaruh suhu terhadap aktivitas CMC-ase (A) dan FP-ase (B) pada kapang Rhizopus spp
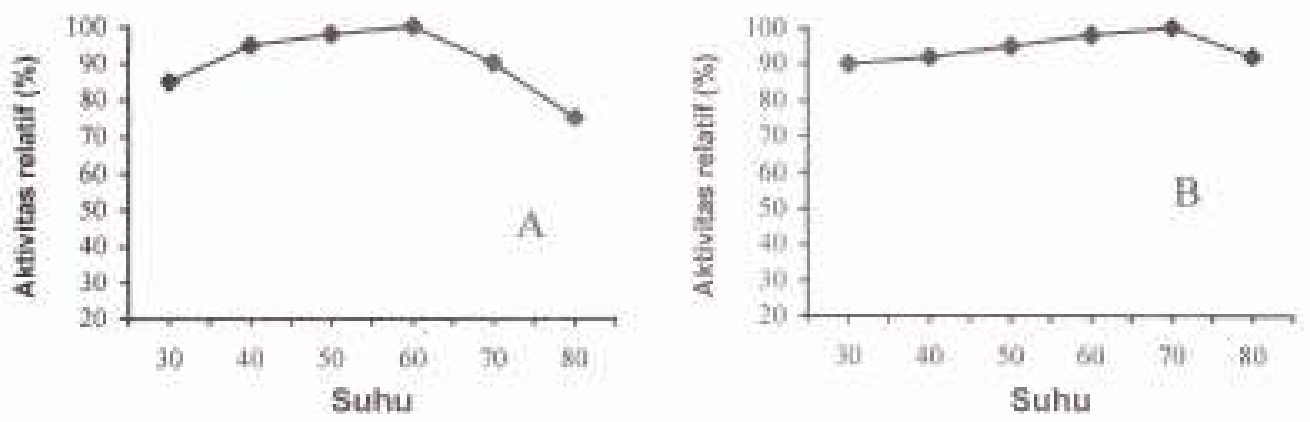

Gambar 9. Stabilitas enzim CMC-ase (A) dan FP-ase (B) pada berbagai suhu dari kapang $T$. viride
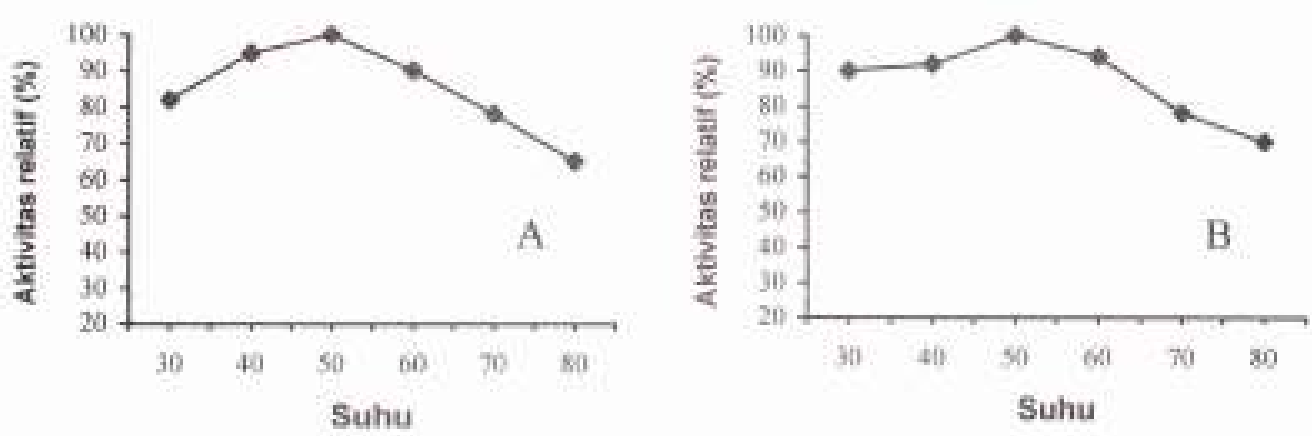

Gambar 10. Stabilitas enzim CMC-ase (A) dan FP-ase (B) pada berbagai suhu dari kapang Rhizopus spp

Enzim dari kapang $T$. viride dan Rhizopus spp akan stabil jika dipanaskan pada suhu $30-80^{6} \mathrm{C}$ selama 10 menit (Gambar 9 dan 10). Kulp (1975) menyatakan bahwa enzim selulase sering menunjukkan sifat tahan panas, sebagai contoh enzim selulase dari Myrothecium werrucaria masih menunujukkan aktivitas $20 \%$ setelah dipanaskan pada suhu $100^{\circ} \mathrm{C}$ selama 10 menit, sedangkan enzim selulase dari Rhizopus stolonifer masih aktif setelah dididihkan selama $10-15$ menit. 
Luasnya kisaran stabilitas enzim terhadap suhu memungkinkan enzim tersebut dapat ditambahkan ke pakan dan memudahkan enzim tersebut dalam penyimpanan. Enzim -enzim yang mempunyai ketahanan terhadap suhu tinggi dapat digunakan lebih luas dalam industri pakan ternak, enzim-enzim tersebut dapat digunakan dalam proses pemeletan bahan pakan. Simon (1996) menyatakan bahwa enzim-enzim yang digunakan untuk pakan temak mempunyai sifat-sifat ketahanan terhadap suhu yang tinggi. Selanjutnya Roxen (1980) menyatakan enzim dapat digunakan dalam pemeletan jika temperatur dalam pemeletan tidak melebihi $70^{\circ} \mathrm{C}$ sehingga enzim tersebut dapat digunakan lebih luas pada pemeletan. Enzim yang dihasilkan oleh kedua kapang diduga dapat bertahan aktivitasnya di dalam rumen, mengingat suhu rumen berada pada kisaran suhu kestabilan enzim. Jika demikian maka teknologi pemakaian enzim dalam ransum ternak ruminansia dapat diterapkan untuk mendukung keterbatasan enzim endogenous dalam rumen dalam memecah pakan berserat.

\section{Kesimpulan}

Kapang yang ditumbuhkan pada substrat jerami padi sebagai satu-satunya sumber karbon dalam media dapat menghasilkan selulase. Aktivitas selulase maksimum dari Trichoderma viride diperoleh pada hari ke-14 dengan konsentrasi substrat $1,5 \%$, sedangkan kapang Rhizopus spp diperoleh pada hari ke11 dengan konsentrasi substrat 1,0 $\%$.

Enzim selulase dari kapang $T$. viride dan Rhizopus spp akan mendapatkan aktivitas selulase yang optimum masing-masing pada $\mathrm{pH} 5$ suhu $60^{\circ} \mathrm{C}$ dan pada pH 5 suhu $50^{\circ}$ C.

\section{Saran}

Perlu diteliti lebih lanjut aktivitas enzim pemecah serat lainnya yang diproduksi oleh Rhizopus spp dan Trichoderma viride serta perlu diteliti lebih lanjut pengaruh penambahan enzim tersebut ke dalam pakan ternak yang memakai limbah pertanian dan industri sebagai komponen utama dalam ransumnya.

\section{Daftar Pustaka}

Aunstrup, K. 1979. Production, isolation and economic of extracellular enzymes. Dalam L. E. Wingart, E. K. Katzir dan Godstein (Ed.). Applied Biochemistry Bioengginering Enzymes Technology. Academic Press, New York

Breuil, C. P., Mayers, dan J. N. Sadler. 1986. Substrate conditions that influence the assays used for determining the $\beta$-glukosidase activity of cellulolytic microorganisme. Biotechnol. Bioeng. 28 : 1653 - 1656.

Chahal, D. S, 1985. Solid state fermentation with Trichoderma reesei for cellulase production. Appl. Environ. Microbiol. 49 : 205 $-210$

Considine, PJ and Coughlan, M .P. 1989. Production of carbohydrat hydrolysis enzymes blends by solid state fermentation.

Dalam 
Coughlan, M P (ed.) Enzymes Sistem for Lignocellulose Degradation. Elsevier Applied Science. London.

Darwis, A. A., E. Sukara. 1990. Penuntun Praktikum Isolasi, Purifikasi dan Karakteristik Enzim. PAU Bioteknologi IPB. Bogor.

Ekawati, I Gusti Ayu. 1993. Pemanfaatan Bonggol Pisang untuk Produksi Enzim Selulase dari Aspergillus niger dan Trichoderma reisei - Thesis. Program Pascasarjana. Intstitut Pertanian Bogor, Bogor.

Enari, T M. 1983. Microbial Cellulases. Dalam W.M. Fogarty (ed.). Microbial Enzymes and Biotechnology. App. Sci. Publ. New York.

Gong, C. S, and G. T. Tsao. 1979. Cellulase and Biosynthesys Regulation. Dalam Peariman (ed.). Annual Report on Fermentation Process, Academic Press. New York.

Irawadi. T. T. 1991. Produksi Enzim Ekstraselular (Selulase dan Xilanase) dari Neurospora sithopila pada Substrat Limbah Padat Kelapa Sawit. [Disertasi] Program Pascasarjana IPB. Bogor.

Jorgensen, O. B, and D. Cowan. 1989. Use of enzyme in feed and ensiling $\mathrm{pp}: 347-355$. Dalam Coughlan M. P (Ed.)
Enzyme System for Lignosellulose Degradation. ed. M.P. Coughlan. Elsevier Appl Sci pp: $347-355$.

Kulp, K. 1975. Carbohydrases. Dalam _ G. Reed (ed.) Enzyme and food Processing. Academic Press, New York.

Landecker, E. M. 1972. Fundamental of the fungi . Prentice Hill Mc. New York University.

Mandels, M., R. Andreotti dan C. Roche. 1976a. Measurement of saccharifying cellulase. Biotechnol. Bioeng. Symp. no. $26: 21-33$

Mandels, M. D. Sternberg and R. E. Andreotti, 1976b in Symp, on enzymatic hydrolysis of cellulase. M. Baylei (Ed). 81.

Martin C., M. J. Negro, M. Alfonsel and R. Saez. 1987. Enzymatic hydrolysis of lignocellulasic biomass from onopardum nervosum. Biotechnol and Bioeng. Vol $32: 341-344$

Okada, G. 1985. Purification and properties of cellulase from Aspergillus niger. Agric. Biol - chem 49 (5) : 1257 - 1265

Peiji, G. 1987. A Simple method for estimating cellobiase activity by determination of reducing sugar. Biotechnol and Bioeng $29: 903-905$

Ramli, N., M. Fujinaga., M. Tabuchi., K. Takagawa dan S. Iwahara. 1995. Isolation an characterization of a novel endo $\beta$ galactofuranosidase 
from bacillus sp. Biosci.

Biotech. Biochem. 59 (10)

$1856-1860$

Roxen. 1980. Use of enzymes biomass in the feedstuff industry in Linko an Larinkari, Food process engineering vol 2 Applied sci publishers. Lodon.

Simon, O. 1996. Enzymes nature's catalysts. Feed mix vol 4. Number $1: 20-28$

Soctjiharto, M. 1997. Isolasi Kapang Tanah Pendegradasi Lignoselulosa Dalam Memperbaiki Nilai Nutrisi Pakan Berserat. Skripsi.
Fakultas Peternakan Institut Pertanian Bogor. Bogor.

Sutopo, T.1987. Pemanfaatan jerami padi pada fermentasi Trichoderma viride untuk menghasilkan selulase. Skripsi. Fakultas Teknologi Pertanian. Institut Pertanian Bogor. Bogor.

Tangnu, S.K., H.W. Blanch and C.R. Wilke. 1981. Enhanced production of cellulase, hemicellulase and $\mathrm{B}$ glucosidase by Trichoderma reesei (Rut c-30). Biotechnol. Bioeng. 23 : 1837 - 1849 .

Alamat korespondensi : Dr. Montesqrit SPt, MSi.

Jurusan Nutrisi dan Makanan Ternak

Fakultas Peternakan Universitas Andalas

Padang

Diterima: 30 April 2007, Disetujui: 22 Mei 2007 